Бодак В.І., Гандзюк М.О., Дубицький О.С., Мазилюк П.В. Луиький національний технічний університет

\title{
АНАЛІЗ СТАНУ ВНУТРІШНІХ ПЕРЕВЕЗЕНЬ В УКРАЇНІ ПРОТЯГОМ 2017-2020 РОКІВ
}

\begin{abstract}
|| Провівши аналіз стану перевезень можна визначити причини, які впливають як на збільшення так і на зменшення обємів перевезень. Причому усунувши негативні причини, які спричиняють зменшення обємів перевезень, можна досягти зворотнього позитивного ефекту, тобто збільшення вантажопотоків та пасажиропотоків. Зменшення вантажопотоків протягом 2017-2020 років залізничним, автомобільним та водним транспортом, що відбулося внаслідок значного скорочення виробництва товарів. Основною причиною зменшення вантажопотоків стало запровадження карантину, повязаного з пандемією Covid-19.

Відмічено,що річкові перевезення поки неконкурентні через низку факторів: застарілість та низьку енергоефективність шлюзів, відсутність стабільної глибини 3,65 м та відсутність належного флоту із сучасними системами навігації.

Україна має значний потенціал для організації логістичних схем перевезення вантажів за участю річкового транспорту на декількох напрямках. Наявність, хоча й дещо застарілої, потужної інфраструктурної бази, зручне географічне розташування та наявність вантажопотоків, що потенційно можуть бути перевезені по внутрішніх водних шляхах створює передумови для відновлення та розвитку цього транспортного напрямку.

Мета статті полягає у дослідженні об'ємів перевезень вантажів та пасажирів в Україні з 2017 року по 2020 рік. Досліджено спад внутрішніх перевезень. Проаналізовано причини цього спаду. Ліквідування причин спаду дозволить збільшити об'єми перевезень в послідуючих роках.

Ключові слова: перевезення, автомобільний транспорт, залізничний транспорт, водний транспорт, вантажні перевезення, пасажирські перевезення.
\end{abstract}

\section{ВСТУП}

За останні роки спостерігається зменшення обємів перевезень як пасажирів так і вантажів.

За офіційними даними статистики об’єми перевезень вантажів та пасажирів в Україні з 2017 по 2020 рік зменшилися. Зменшення вантажопотоків та пасажиропотоків спричинила не тільки пандемія COVID-19.

\section{АНАЛІЗ ЛІТЕРАТУРНИХ ДАНИХ ТА ПОСТАНОВКА ПРОБЛЕМИ}

Згідно інформації викладеної на сайті http://www.ukrstat.gov.ua, об’єми вантажопотоків мали значення представлені на рис. 1

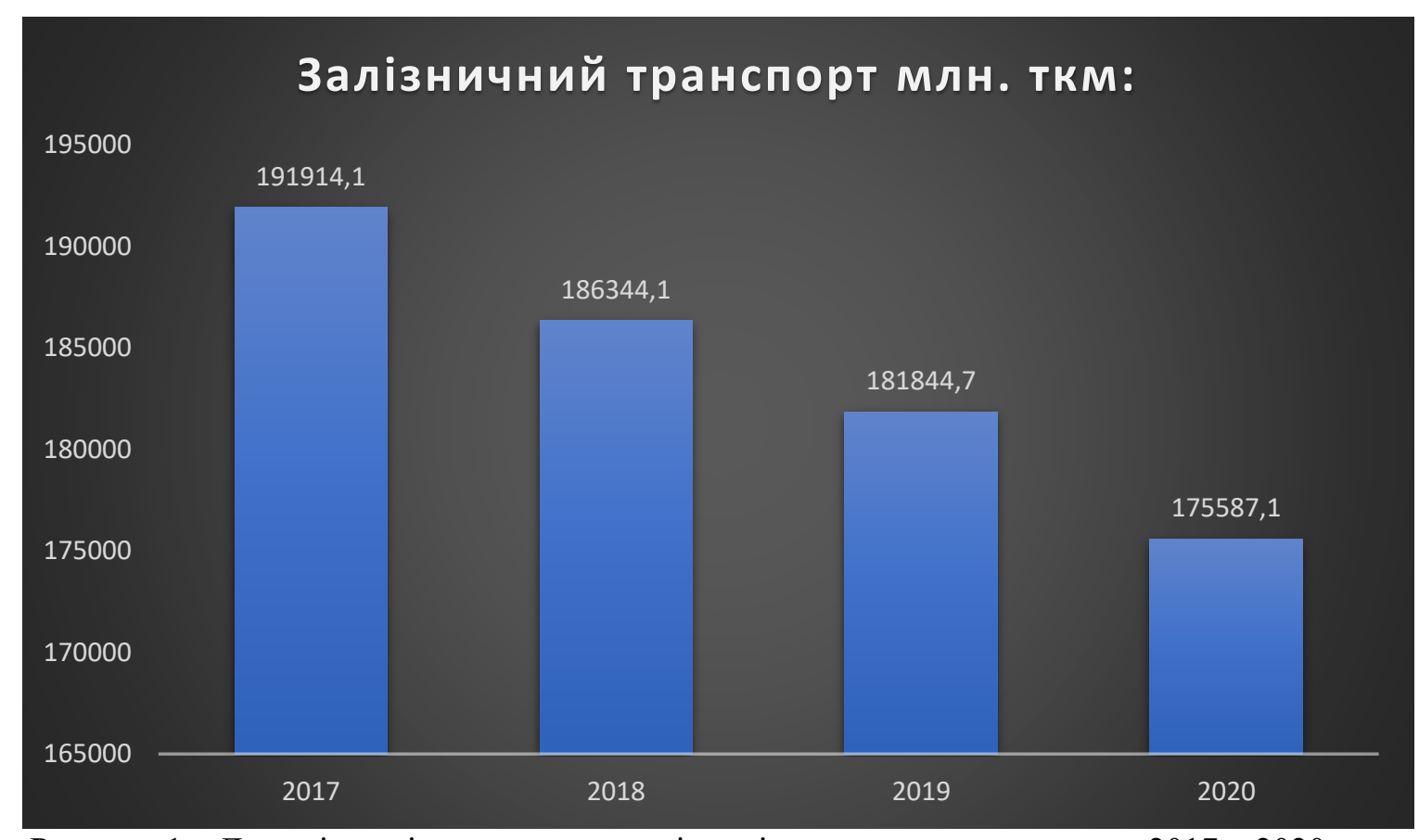

Рисунок 1 - Динаміка зміни вантажопотоків залізничним транспортом за $2017-2020$ роки 
() Бодак В.І., Гандзюк М.О., Дубицький О.С., Мазилюк П.В. 2021

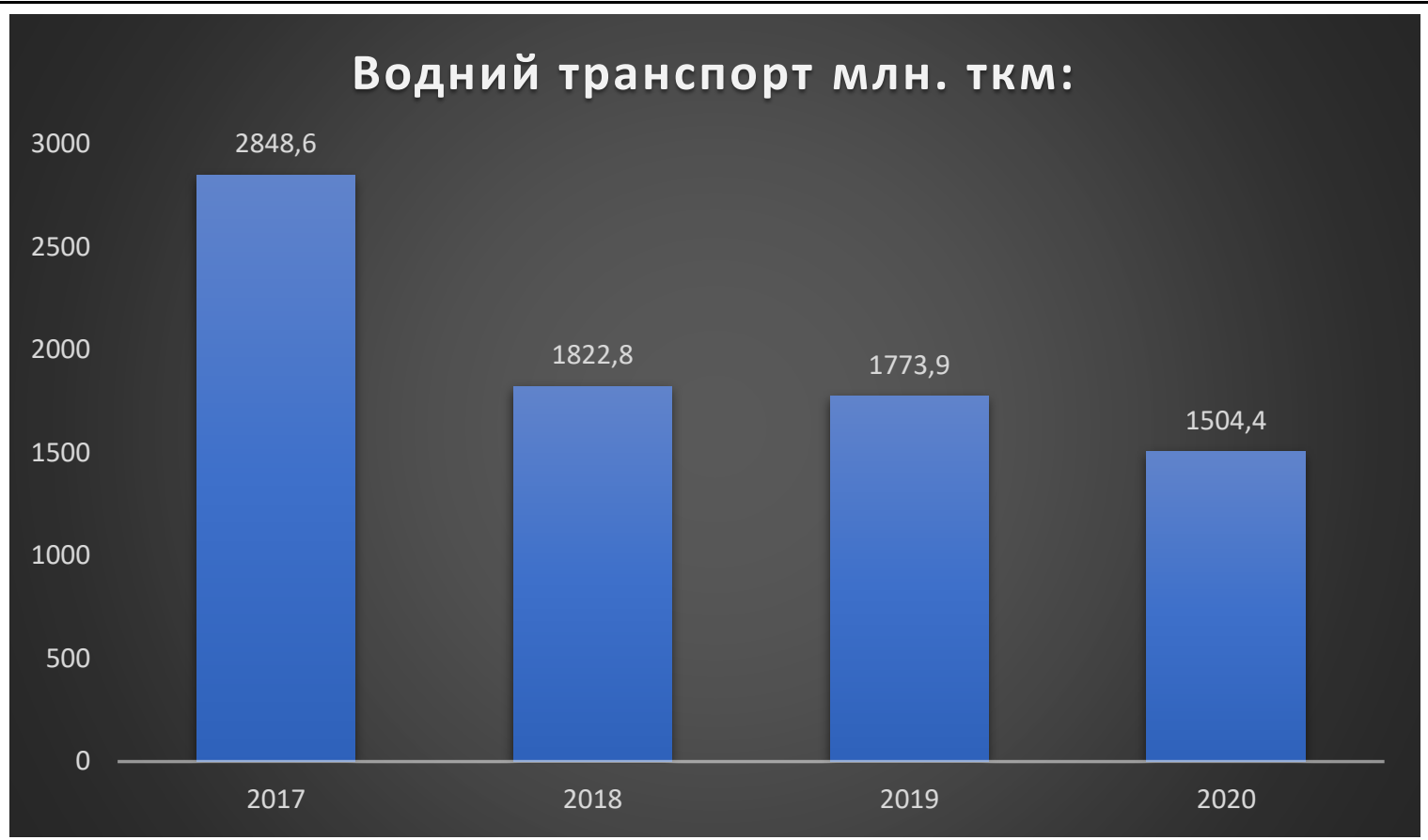

Рисунок 2 - Динаміка зміни вантажопотоків водним транспортом за 2017 - 2020 роки

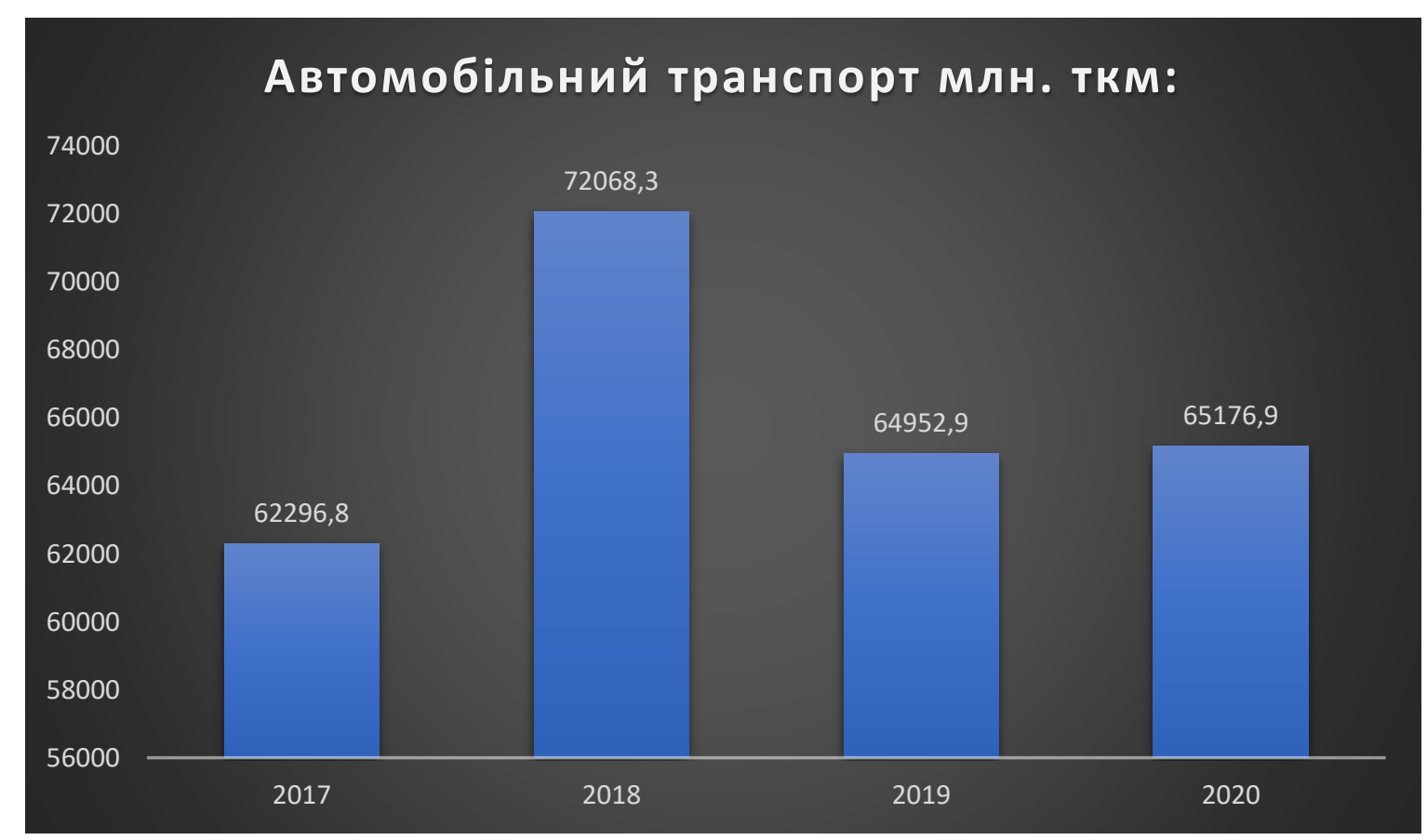

Рисунок 3 - Динаміка зміни вантажопотоків автомобільним транспортом за $2017-2020$ роки 


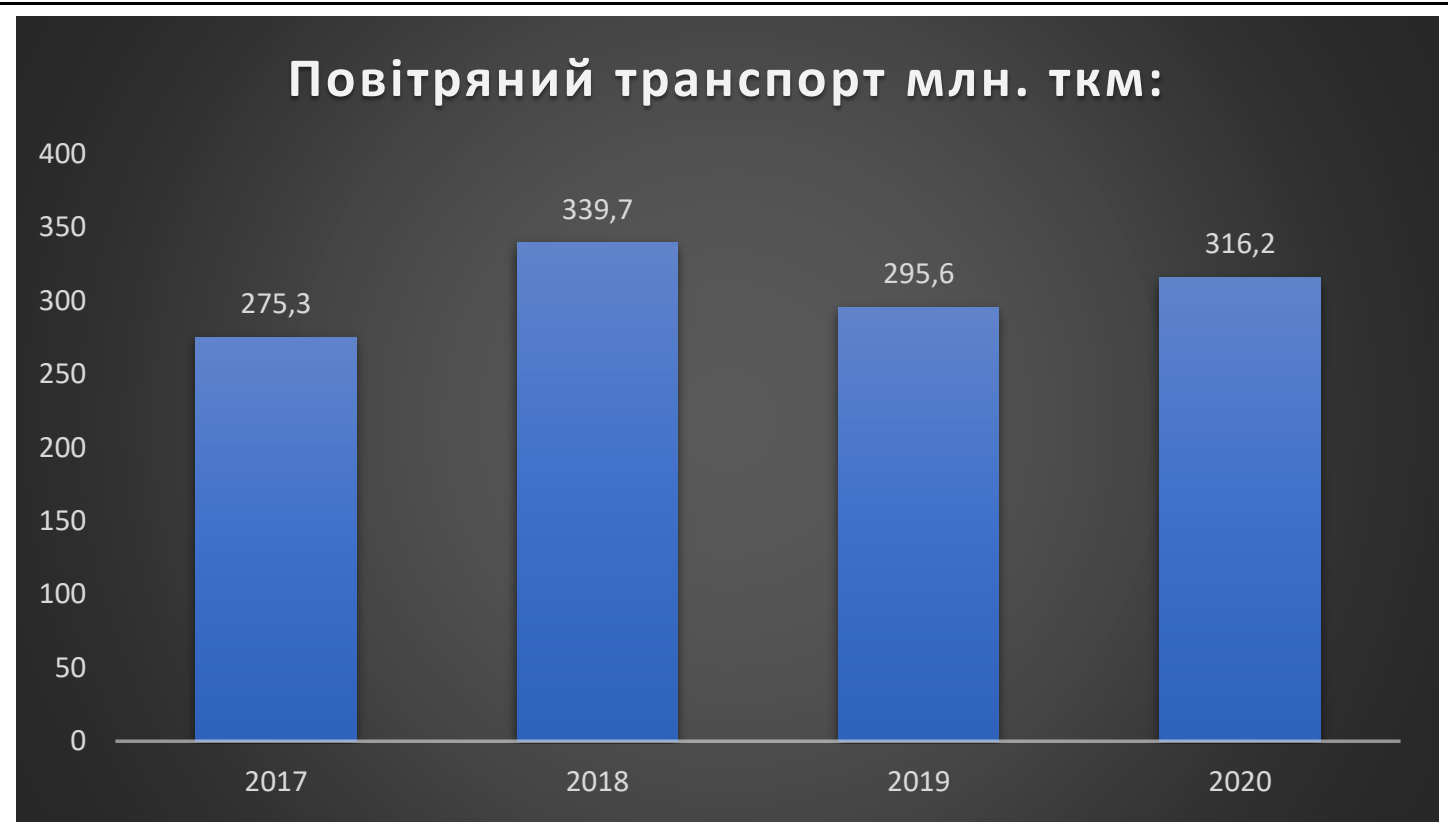

Рисунок 4 - Динаміка зміни вантажопотоків повітряним транспортом за 2017 - 2020 роки

За даними річкової інформаційної служби України (PIC) філії «Дельта-Лоцман», за підсумками перших 4-х місяців 2021 року вантажні річкові перевезення Дніпром склали 3,12 млн тонн і збільшилися на 1,2 млн тонн у порівнянні з аналогічним періодом 2020 року.

Старт реформи річкових перевезень і відновлення внутрішніх водних шляхів залишаються одним із пріоритетних завдань Мінінфраструктури на 2021 рік. І продовжується активна підготовка відповідних документів для імплементації нового закону «Про внутрішній водний транспорт», а також для створення окремого Держфонду внутрішніх водних шляхів, 3 якого в майбутньому модернізуватиметься та відновлюватиметься необхідна річкова інфраструктура. Відтак, протягом січня-квітня поточного року було здійснено 3465 рейсів у порівнянні з 1694 рейсами за аналогічний період 2020-го.

\section{ЦІЛЬ ТА ЗАДАЧІ ДОСЛІДЖЕННЯ}

Мета статті полягає у дослідженні об’ємів перевезень вантажів та пасажирів в Україні з 2017 року по 2020 рік. Досліджено спад внутрішніх перевезень. Проаналізовано причини цього спаду. Ліквідування причин спаду дозволить збільшити об'єми перевезень в послідуючих роках.

\section{РЕЗУЛЬТАТИ ДОСЛІДЖЕНЬ}

В результаті обробленої інформації слід відмітити, що основна частка вантажів - будівельні, обсяги транспортування яких виросли на $126 \%$ і досягли 1,97 млн тонн. На другому місці - зерно (804,8 тис. тонн). Також річковим транспортом активно перевозиться металопродукція (340 тис. тонн).

Необхідно надалі проводити роботи по поглибленню фарваторів річок Дніпро та Припять для проходу великотонажних суден.

Зараз контейнерні перевезення річкою не можуть конкурувати із залізницею через стан річкової інфраструктури. Про це вказано і в Концепції розвитку мультимодальних перевезень в Україні, яку представило Міністерство інфраструктури.

Річкові перевезення поки неконкурентні через низку факторів: застарілість та низьку енергоефективність шлюзів, відсутність стабільної глибини 3,65 м та відсутність належного флоту із сучасними системами навігації. 


\section{Стан річкових контейнерних перевезень, тон :}

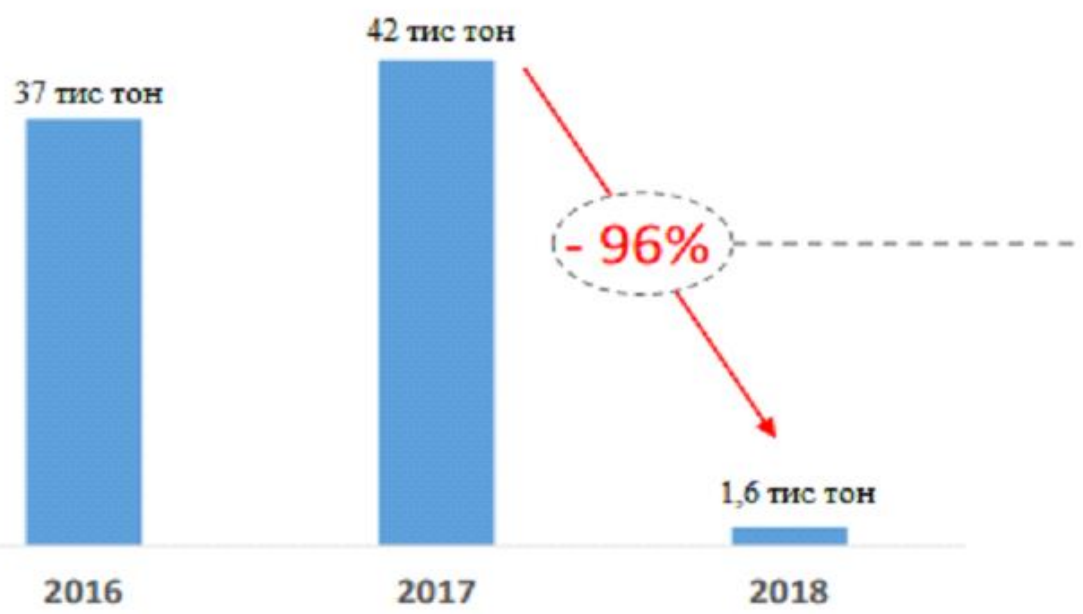

Рисунок 5 - Динаміка зміни контейнерних перевезень річковим транспортом

Так, у 2017 році річкою перевезено 42 тис. тонн, тоді як в 2018 році показник впав на 96\% до 1620 тонн. Причина - запуск контейнерного потягу Чорноморська (ТIC) - НижньодніпровськПристань (Укррічфлот), який показав значну ефективність та перевагу над перевезеннями контейнерів річкою.

У 2020 році літаками перевезено 1,8 мільярда осіб. Востаннє такі показники були ще 2003 року. Для порівняння, 2019 року літаки перевезли понад 4,5 мільярда людей. Загальні втрати 2020 року склали 370 мільярдів доларів. (https://mtu.gov.ua)

Через пандемію коронавірусу авіаперевезення були обмежені. Це призвело до банкрутства менших авіакомпаній.

У 2021 році авіаперевезення залежні від епідеміологічної ситуації в різних країнах, тому існують різні варіанти розвитку подій. Кількість пасажирів може збільшитись на $71 \%$, при сприятливих умовах в порівнянні 2020 роком (до 53\% на міжнародних авіалініях і до $84 \%$ на внутрішніх), при несприятливих умовах - лише до 49\%.

У грудні 2020 року Wizz Air відновив польоти з Києва до Копенгагена, Пардубіце, Біллунна, Відня, Кракова, Лісабона, Гамбурга, Будапешта, Неаполя, Познані, Братислави, Катовіце. Зі Львова відновили польоти до Берліна, Щецина, Братислави, Пардубіце, Вільнюса, а також із Харкова до Кракова, Дортмунда, Відня, Гданська та Вроцлава. Однак виконання реального рейсу відбувається при сприятливій епідеміологічнії ситуації в конкретному місці й рішень місцевої влади.

Аеропорти працюють за новими правилами. В терміналі мають право перебувати лише пасажири, члени екіпажу та обслуговуючий персонал. У приміщенні усі мають бути у масках. Пасажирам, які прилітають та відлітають, вимірюють температуру та при необхідності роблять ПЛРтест.

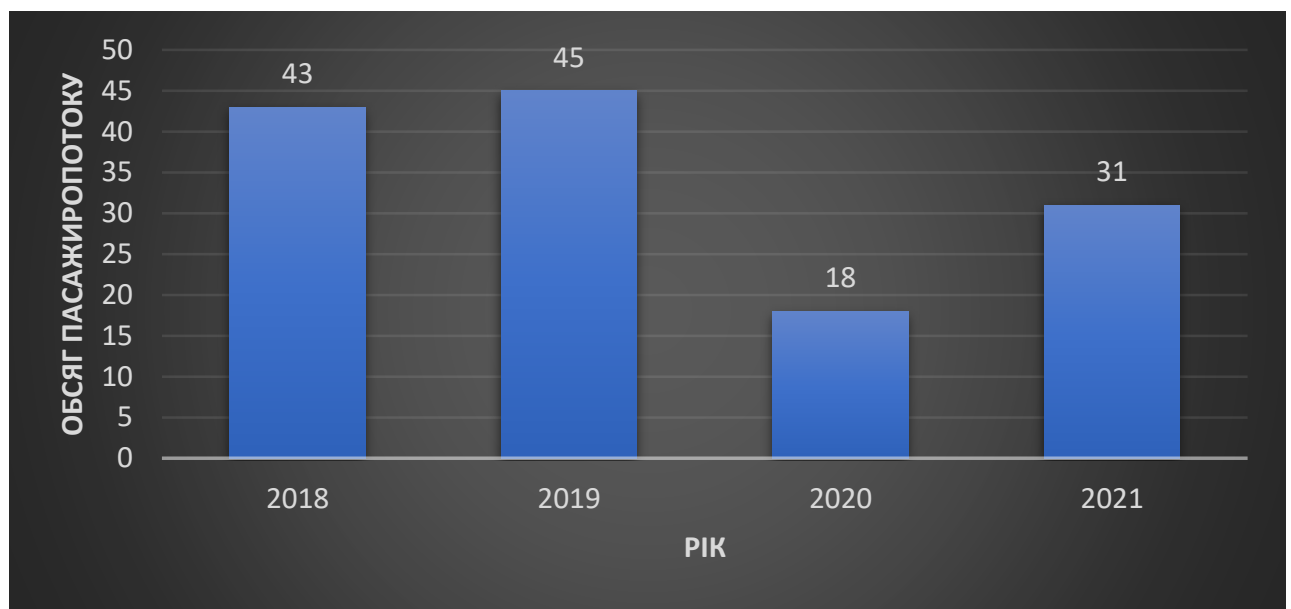

Рисунок 6 - Динаміка зміни пасажиропотоків повітряним транспортом 


\section{ОБГОВОРЕННЯ РЕЗУЛЬТАТІВ ДОСЛІДЖЕННЯ}

2021 рік відзначився зростанням обсягів пасажирських перевезень. За даними Державіаслужби України, загалом українські аеропорти надали послуги 20,5455млн. пасажирів, що на 24,5\% перевищує аналогічні показники 2020 року. Переважна більшість цього пасажиропотоку припала на міжнародні рейси - близько 18,4 млн., тобто практично 90\%. Потреба в недорогих авіаперевезеннях Україною залишається, більш того, авіаційне сполучення в межах країни й надалі залишається здебільшого дорогим.

\section{ВИСНОВКИ}

Україна має значний потенціал для організації логістичних схем перевезення вантажів за участю річкового транспорту на декількох напрямках. Наявність, хоча й дещо застарілої, потужної інфраструктурної бази, зручне географічне розташування та наявність вантажопотоків, що потенційно можуть бути перевезені по внутрішніх водних шляхах створює передумови для відновлення та розвитку цього транспортного напрямку.

Проаналізувавши вищеприведені результати можемо відмітити, що у 2020 році значно зменшились об'єми перевезень вантажів та пасажирів. У 2021 році об'єми перевезень зросли. На такі зміни значно вплинула пандемія COVID-19. Очевидно що i в подальшому спад чи ріст захворюваності на коронавірус впливатиме на динаміку виробництва товарів, а отже, і на зміну об'ємів перевезень.

\section{ПЕРЕЛІК ДЖЕРЕЛ ПОСИЛАННЯ}

1. www.mtu.gov.ua - офіційний сайт Міністерства інфраструктури

2. www.ukrstat.gov.ua - сайт держстатистики

3. Математические методы моделирования и оперативного планирования перевозок на автотранспорте [Текст] : [монография] / В. Г. Галушко. - К. : НТУ, 2013. - 198 с.

4. Проблемы теории и практики развития морского транспорта Украины [Текст] : науч. моногр. / Котлубай Алексей Михайлович ; Нац. акад. наук Украины, Ин-т проблем рынка и экон.экол. исслед. - О. : ИПРЭЭИ НАН Украины, 2011. - 267 с.

5. Методологічні підходи до модернізації транспортної системи України [Текст] : монографія / Н. В. Кудрицька. - К. : НТУ, 2013. - 127 с.

6. Логістичне управління та безпека руху на транспорті. Науково-практична конференція студентів та молодих вчених, 18-20 листопада 2015 року, м. Харків [Текст] : зб. наук. пр. / Східноукр. нац. ун-т ім. Володимира Даля, Каф. "Логіст. упр. та безпека руху на трансп." [та ін.] ; [відп. ред. Чернецька-Білецька Н. Б.]. - Сєвєродонецьк : СНУ ім. В. Даля, 2015. - 184 с.

\section{REFERENCE}

1. www.mtu.gov.ua is the official website of the Ministry of Infrastructure

2. www.ukrstat.gov.ua - site of state statistics

3. Mathematical methods of modeling and operational planning of transportation by motor transport [Text]: [monograph] / V.V. G. Galushko. - K.: NTU, 2013. - 198 c.

4. Problems of theory and practice of development of maritime transport of Ukraine [Text]: science. monograph / Kotlubay Alexey Mikhailovich; Nat. acad. Sciences of Ukraine, Inst. of Market Problems and Economics. research. - NAN Ukraine, 2011. - 267 c.

5. Methodological approaches to the modernization of the transport system of Ukraine [Text]: monograph / NV V. Kudrytska. - K.: HTY, 2013. - 127 c.

6. Logistics management and traffic safety. Scientific and practical conference of students and young scientists, November 18-20, 2015, Kyiv, st. Kharkiv [Text]: coll. Science. etc. / East Ukrainian. nat. Univ. Vladimir Dahl, Dept. "Logistics management and traffic safety on transport." [etc.] ; [resp. ed. ChernetskayaBiletskaya NB]. - Severodonetsk: SNU named after V. Dalya, 2015. - 184 p.

Bodak V.I., Gandziuk M.O., Dubitsky O.S., Mazilyuk P.V. Analysis of the state of domestic transportation in ukraine during 2017-2020

After analyzing the state of traffic, you can identify the reasons that affect both the increase and decrease in traffic. Moreover, eliminating the negative causes that cause a decrease in traffic, you can achieve the opposite positive effect, ie an increase in freight and passenger traffic. Reduction of freight flows during 2017-2020 by rail, road and water transport, which occurred due to a significant reduction in the 
production of goods. The main reason for the decrease in freight traffic was the introduction of quarantine related to the Covid-19 pandemic.

It is noted that river transport is still uncompetitive due to a number of factors: obsolescence and low energy efficiency of locks, lack of stable depth of $3.65 \mathrm{~m}$ and lack of proper fleet with modern navigation systems.

Ukraine has significant potential for the organization of logistics schemes for the transportation of goods involving river transport in several directions. The presence of, albeit somewhat outdated, powerful infrastructure base, convenient geographical location and the presence of freight flows that can potentially be transported by inland waterways creates the preconditions for the restoration and development of this transport direction.

The purpose of the article is to study the volume of cargo and passenger traffic in Ukraine from 2017 to 2020. The decline in domestic traffic has been studied. The reasons for this decline are analyzed. Eliminating the causes of the recession will increase traffic in the coming years.

Key words: transportation, road transport, railway transport, water transport, freight transportation, passenger transportation.

БОДАК Володимир Іванович, кандидат технічних наук, доцент кафедри автомобілів і транспортних технологій Луцького національного технічного університету, e-mail: bodak.lutsk@gmail.com. https://orcid.org/0000-0003-2521-7305.

ГАНДЗЮК Микола Олексанлрович, кандидат технічних наук, доцент кафедри автомобілів і транспортних технологій Луцького національного технічного університету, e-mail: Gandzyuk64.MG@ gmail.com. http://orcid.org/0000-0002-3552-4256.

ДУБИЦЬКИЙ Олександр Сергійович, кандидат технічних наук, доцент кафедри автомобілів і транспортних технологій Луцького національного технічного університету, e-mail: oleksandr.dubytskyi@lutsk-ntu.com.ua. https://orcid.org/0000-0002-4863-4040.

МАЗИЛЮК Павло Вікторович, кандидат технічних наук, доцент кафедри автомобілів і транспортних технологій Луцького національного технічного університету, e-mail: mazylyuk@ukr.net. https://orcid.org/0000-0001-5071-5109.

Volodymyr BODAK, Ph.D in Engeneering, associate professor of automobiles and transport technologies department, Lutsk National Technical University, e-mail: bodak.lutsk@gmail.com. https://orcid.org/0000-0003-2521-7305.

Mykola GANDZYUK, Ph.D in Engeneering, associate professor of automobiles and transport technologies department, Lutsk National Technical University, e-mail: Gandzyuk64.MG@gmail.com. http://orcid.org/0000-0002-3552-4256.

Oleksandr DUBYTSKYI, Ph.D in Engeneering, associate professor of automobiles and transport technologies department, Lutsk National Technical University, e-mail: oleksandr.dubytskyi@lutskntu.com.ua. https://orcid.org/0000-0002-4863-4040.

Pavlo MAZYLYUK, Ph.D in Engeneering, associate professor of automobiles and transport technologies department, Lutsk National Technical University, e-mail: mazylyuk@ukr.net. https://orcid.org/0000-0001-5071-5109.

DOI 10.36910/automash.v2i17.633 